\title{
THE INFLUENCE OF THE TECHNICAL DIMENSION, FUNCTIONAL DIMENSION, AND TENANT SATISFACTION ON TENANT LOYALTY: AN ANALYSIS BASED ON THE THEORY OF PLANNED BEHAVIOR
}

\author{
Chun-Chang LEE ${ }^{1}$, Lou-Jung TING ${ }^{1}$, Wen-Chih $\mathrm{YEH}^{2, *}$, Zheng YU \\ ${ }^{1}$ Department of Real Estate Management, National Pingtung University, Pingtung, Taiwan \\ ${ }^{2}$ Department of Real Estate Management, HungKuo Delin University of Technology, New Taipei, Taiwan \\ ${ }^{3}$ Department of Land Economics, National Chengchi University, Taipei, Taiwan
}

Received 26 March 2021; accepted 08 July 2021

\begin{abstract}
This study primarily explored the influence of the technical dimension, functional dimension, and tenant satisfaction on tenant loyalty. The theory of planned behavior served as the basis of this study, and the three aforementioned factors (the technical dimension, the functional dimension, and tenant satisfaction) were incorporated into a conceptual framework for tenant loyalty. Structural equation modeling (SEM) was employed for parameter estimation. The participants consisted of tenants residing in eight administrative districts in Kaohsiung City. 315 questionnaires were administered, all of which were returned. After removing 15 invalid responses, there were 300 valid responses, which indicated an effective recovery rate of $95.2 \%$. The results showed that the technical dimension, the functional dimension, and attitude significantly and positively influenced tenant satisfaction. Tenant satisfaction, perceived behavioral control, and social norms significantly and positively influenced tenant loyalty. Tenant satisfaction mediated the influence of the technical dimension and the functional dimension on tenant loyalty; the mediating effect of the functional dimension on tenant loyalty was greater than that of the technical dimension. The findings of this study highlight the measures rental companies should adopt in order to enhance the technical dimension, functional dimension, and tenant satisfaction, as this is crucial to maintaining sustainable operations.
\end{abstract}

Keywords: perceived behavioral control, social norms, technical dimension, functional dimension, tenant loyalty.

\section{Introduction}

The house price to income ratio in Taiwan has soared over the past few years, peaking at 9.46 in the second quarter of 2017. Facing the high house price to income rate, people are willing to rent houses instead of purchasing. According to Directorate General of Budget, Accounting and Statistics' General Report of 2010 Population and Housing Census, ${ }^{1}$ approximately 800.000 people in Taiwan had the need to rent a house. In Kaohsiung City, there were 96.000 such people, which accounted for $12 \%$ of the nationwide total and puts the city among the top three cities/ counties in Taiwan with the highest demand for housing rentals. This highlights the importance and gradual expansion of the rental market. Landlords should contem-

\footnotetext{
1 Directorate General of Budget, Accounting and Statistics - Census GIS Platform, 2018, House ownership of ordinary households. https://census.dgbas.gov.tw/CensusGIS_Tile/?ClassIndex=1. Accessed on February 23, 2019.
}

plate the means of enhancing housing quality, understand tenants' motivations to rent, and plan and provide goods or services that meet tenants' demands, so as to enhance tenant retention and maintain long-term and stable landlord-tenant relationships. Meanwhile, landlords must also scrutinize how they can enhance tenant satisfaction and loyalty and reinforce their competitive advantage in the rental market, thus increasing their survival in a fiercely competitive market as well as ensuring their sustainable operations.

A multitude of factors influence tenant loyalty, and many authors have employed the theory of planned behavior (TPB) for the theoretical analysis of these factors. Ajzen and Fishbein (1980) suggested that all the factors that could possibly influence a person's behavior indirectly affect their behavioral performance through behavioral intentions. Behavioral intentions are affected by three interrelated factors, one of which is a person's attitudes, that

*Corresponding author. E-mail: wen00126@mail.hdut.edu.tw 
is, the attitudes they have toward a particular behavior. According to Fazio and Zanna $(1978,1981)$, a person's attitude affects their behavioral intentions. Moreover, attitudes are derived from extrinsic subjective norms (such as personal norms, behavioral norms, and social norms) which influence the particular behaviors performed by a person. Lastly, attitudes are a result of perceived behavioral control. Firstly, in terms of the effect of attitude on tenant loyalty, when customers display a stronger brand attitude toward a particular brand, they would have a higher brand loyalty. Customers also bond with the brand through their emotional attachment, thus influencing their brand loyalty as well as the price premium that they are willing to pay (Lin et al., 2016). Next, with regard to the relationship between perceived behavioral control and loyalty, Ajzen (1987) argued that adding the variable of perceived behavioral control into the theory of planned behavior increases the explanatory and predictive strengths of behavioral intentions. Similar to the concept of self-efficacy, perceived behavioral control is a notion based on one's capabilities, and also influences one's expression of their behavioral intentions. Lastly, according to the theory of planned behavior, social norms (a component of subjective norms) refer to the social pressure perceived by a person when they engage in a particular behavior, or whether significant others support such behaviors (Ajzen, 1980). For example, even though tenants are willing to retain their tenancy with landlords with a good attitude, due to the impact of social norms, tenants would have less willingness to retain their tenancy. This shows that social norms have a substantial influence on loyalty. The association between cause and effect is important for real estate companies, as a landlord and a tenant establish their relationship based on the tangible (internal or external appearance, interior design planning and external transport accessibility) and intangible (relationships, services, laws and regulations) facilities of a building. Most of the time, a tenant would consider the internal or external attributes of a house that they intend to rent. Across the multitude of studies regarding real estate rentals, some analysed how an office's building and location affect the satisfaction and loyalty of tenants (AppelMeulenbroek, 2008), some explored the evaluation strategies and satisfaction of tenants (Palm, 2016), and some examined the association between their satisfaction and lease renewal intentions (Sanderson, 2019). However, to the best of our knowledge, no study thus far has analysed tenant satisfaction and loyalty by linking TPB components (attitudes, perceived behavioural control and social norms) and the technical and functional dimensions related to a building's interior and exterior. To this end, this study used the TPB framework as well as the technical and functional dimensions of service quality to evaluate and analyse the building's external attributes (transport accessibility and convenience), interior design planning, and the quality of service provided by the landlord.

Tenant satisfaction is a salient factor influencing tenant loyalty, and thus, factors that influence tenant satisfaction should be taken into account. For instance, facility management is a factor influencing tenants' satisfaction with rented buildings. Secondly, perceived quality is another important factor influencing tenants' contentment. Tenant satisfaction reflects tenant loyalty and recommendation of landlords to others (Seetharaman et al., 2017). Myeda et al. (2011) identified two dimensions of building management and maintenance: The technical dimension encompasses maintenance services, cleaning, landscaping, lighting, air-conditioning, elevators, sanitary facilities, washing facilities, etc.; the functional dimension encompasses the delivery, reliability, and responsiveness of management services. Kang and James (2004) opined that the technical and functional dimensions of service quality influence customers' brand perception of a service provider. In other words, the technical and functional dimensions influence tenant satisfaction. A number of authors hold the position that the technical and functional dimensions are two important factors behind tenant satisfaction and loyalty (Adnan et al., 2012; Muhlebach, 1998; Kusbit \& Sutton, 1991; Hong \& Chang, 1993).

In terms of the technical dimension, Hung and Chang (1993) indicated that housing quality encompasses the substantive aspect and the non-substantive aspect. The former should consist of attributes related to housing quality, the housing building itself, and the neighborhood where the building is located; the latter should consist of housing services provided or the users' subjective perceptions and satisfaction toward the services. The aforementioned substantive aspect is the technical dimension in this study, which refers to the building's tangible facilities, housing quality, and living environment. The non-substantive aspect is the functional dimension in this study, and empirical results showed that this dimension exerts the greatest influence on housing satisfaction (Hung \& Chang, 1993). Kusbit and Sutton (1991) concurred that the interior image of a building is a salient factor that influences tenant satisfaction. Muhlebach (1998) pointed out that enhancing the building's interior and exterior appearances would increase tenants' willingness to retain their tenancy.

Secondly, the functional dimension (process) encompasses service (quality) delivery, that is customers' perception of interactions that occurred during the service delivery process. Naudé and Buttle (2000) defined relationship quality as the quality perceived by customer; a high relationship quality helps enhance the customers' perceived quality and thus strengthens long-term relationships. Malik (2012) suggested that in essence, customers' perceptions of service quality are subjective and highly correlated to the service quality provided. Rasila (2009) argued that honest landlords who continuously share information and communicate with tenants increase the relationship quality between them and their tenants. Gounaris et al. (2010) opined that service quality affects customers' purchase satisfaction and behavioral intentions. Hence, housing quality, quality of living environment, service quality, and perceptions of service are all variables that could be included into the technical and functional dimensions of the scope of this study. 
This study primarily aimed to examine the factors influencing personal behavior on tenant loyalty. The theory of planned behavior (which encompasses attitude, perceived behavioral control, and social norms) served as the basis of this study; and the three variables of the technical dimension, the functional dimension, and tenant satisfaction were incorporated into a conceptual framework on tenant loyalty.

\section{Literature review and research hypotheses}

In the study by Cheah et al. (2014) concerning the effects of the technical and functional dimensions of tenant satisfaction and loyalty, the technical dimension consisted of five aspects - building features and service preference, agglomeration, accessibility, lease and monetary performance, while the functional dimension consisted of two aspects - proactive customer orientation and responsive customer orientation. Three aspects, namely building features and service preference, agglomeration, and responsive customer orientation significantly and positively affected satisfaction. Lastly, satisfaction also significantly and positively affected loyalty. Similarly, Cheah et al. (2019) divided customer orientation into proactive customer orientation and responsive customer orientation, both of which affect tenant loyalty through tenant satisfaction as a mediator. In addition, office building grade had moderating effects. Cheah et al. (2020) found that the willingness of office tenants to pay rent can be reflected through the perceived benefits of positioning strategies, the grades of office spaces, and industry sectors of office tenants.

\subsection{The technical dimension, the functional dimension, attitudes, and tenant satisfaction}

Adnan et al. (2012) divided the technical dimension into five components: building features, services, and management (BFSM); monetary factors; leasing factors; agglomeration and location; and accessibility. The authors opined that these five factors are key considerations during tenancy decision-making. Tenants who stay for longer periods inside a building are better able to identify with its functions such as clearance height, comfortable working environments, designs, and refurbishments. This identification directly influences their perceptions toward the surroundings of the rented space (Baharum et al., 2009). Gibler et al. (2014) suggested that tenants could encounter losses from reduced business when they move their offices to new locations, and landlords may not necessarily understand why tenants wish to move elsewhere. However, if landlords refurbish their office buildings, they could reduce tenant dissatisfaction, as tenants could feel satisfied with the improvements in the qualities of the office building as well as the services provided by the landlord, thereby increasing their retention. Kusbit and Sutton (1991) concurred that the interior image of a building is a salient factor that influences tenant satisfaction. Kirkpatrick and Tarasuk (2011) pointed out that housing prod- ucts, accessibility, features of the public sector, and environmental features are factors that influence customers' satisfaction with their living arrangement. According to Appel-Meulenbroek (2008), parking facilities, locational factors (close to the city center and public infrastructure), and accessibility exert a positive influence on tenant satisfaction. The main determinant of tenant satisfaction is the value perceived by tenants toward using a paid product or service (Lemke et al., 2011). Hung and Chang (1993) delineated the relationship between the services provided in a community, the quality of management and maintenance, and the satisfaction of living. Living satisfaction mostly entailed the technical dimension, especially the relationship between the housing building itself and customer satisfaction. Based on the aforementioned arguments, we proposed Hypothesis 1 as follows:

$\mathrm{H} 1$ : The technical dimension has a positive and significant influence on tenant satisfaction.

The functional dimension (process) involves how services are provided to customers, that is, customers' perceptions of the interactions that occurred during the service delivery process (Kang, 2006). Flint et al. (2011) identified two functional dimensions, namely proactive customer orientation and responsive customer orientation. Both dimensions can be regarded as factors that create excellent value for customers (Beverland et al., 2004). Freybote and Gibler (2011) noted that providing excellent value, handling sensitive information correctly, maintaining good communications and interpersonal relationships are opportunities for landlords or service providers to demonstrate their knowledge and competence, thereby gaining trust from customers as well as maintaining longterm landlord-tenant relationships. Nath et al. (2010) reported that if enterprises driven by market needs are able to emphasize the service contents and service quality required by customers, they would be able to allocate resources efficiently according to different competitive markets, thereby elevating their performance in terms of innovation. Responsive customer orientation refers to a service provider's ability to effectively respond to the precise needs of customers (Blocker et al., 2011). Hui et al. (2014) pointed out that tenants who live in excellent living environments and have a stronger sense of community belonging have a higher satisfaction of living and are less willing to move out. Based on the aforementioned arguments, we proposed Hypothesis 2 as follows:

$\mathrm{H} 2$ : The functional dimension has a positive and significant influence on tenant satisfaction.

Attitudes are positive or negative evaluations of people, events, and objects. The perceptions and attitudes toward an evaluation consist of three components, namely a cognitive component, an emotional component, and a behavioral component. The behavioral component of attitude refers to the behavioral intentions expressed extrinsically toward a specific behavior, person, event, or object. The behavioral component describes how different behavioral attitudes result in different behavioral expressions, such 
as a love and hatred of certain people, events, and objects. Therefore, an attitude is a combination of affective feelings, cognitive ideas, and intended behaviors (Robbins, 1994). The quality of the living environment is a concept pertaining to the quality of life. It displays the various welfare and feelings of residents toward their living environment, i.e. the effect of residents' attitude on their satisfaction. Lercher (2003) and Bonaiuto et al. $(2003,2006)$ remarked that behavioral intentions directly and positively influence residents' satisfaction. Based on the aforementioned arguments, we proposed Hypothesis 3 as follows:

H3: Attitudes have a positive and significant influence on tenant satisfaction.

\subsection{Attitudes, tenant satisfaction, perceived behavioral control, social norms, and tenant loyalty}

The company's goal is to create profits and retain customers. Customers who identify with a particular product or service have a higher willingness to return in the future. Therefore, enhancing attitudes and strengthening one's trust in a particular product are the means to enhance consumers' propensity of making repeat purchases (Smith \& Swinyard, 1988). Zheng et al. (2019) investigated the factors influencing the behavioral intentions and actual actions among the younger generation on housing rentals. Their empirical results showed that a stronger perceived rental behavior significantly and positively influences behavioral intentions. Based on the aforementioned arguments, we proposed Hypothesis 4 as follows:

H4: Attitudes have a positive and significant influence on tenant loyalty.

In recent years, tenants have raised their expectations for tenancy services. Professionals often regard customer relations management as a factor that determines whether rental companies gain profits (Kennedy \& Schneider, 2000). Gibler et al. (2014) revealed that tenants who are satisfied with their rented house, landlord, or building management are more likely to retain their tenancy. Falco (2017) examined resident satisfaction and showed that community management is a salient factor that determines retention. Enhancing tenants' willingness to retain and strengthening tenant loyalty maximize profits for landlords. With the exclusion of moving out due to non-voluntary factors, tenants who are satisfied with the living environment or service quality provided by their landlords would directly express their intentions to retain their tenancy, as well as promoting or recommending their landlord to their friends and family (Chen \& Shiu, 2016). Based on the aforementioned arguments, we proposed Hypothesis 5 as follows:

H5: Tenant satisfaction has a positive and significant influence on tenant loyalty.

Perceived behavioral control represents the competence, opportunities, time, and resources required by a person to perform a behavior (Ajzen, 1985, 1991). The greater the perceived behavioral control, the stronger a person is able to control themselves to perform a behavior, thereby enhancing their behavioral intentions (Ajzen \& Madden, 1986). Gasiorowska (2014) proposed that during the transaction of goods, perceived behavioral control influences a consumer's ability to pay for the goods they have purchased, and affordability acts as a variable that influences purchase intentions. The author asserted that perceived behavioral control effectively affects purchase intentions. Based on the aforementioned arguments, we proposed Hypothesis 6 as follows:

H6: Perceived behavioral control has a positive and significant influence on tenant loyalty.

Roos and Hahn (2017) found potential interactions between social norms and customer behaviors in the context of living space under a shared economy. The stronger the consumers' engagement in shared consumption, the more interactions and attention between one another. This ultimately creates highly reliable social norms among consumers, as well as the willingness to engage in shared living with others and loyalty to a living space. Kim et al. (2015) pointed out that social norms are socially-derived normative pressures on a person's behavior, in which injunctive norms represent the degree of acceptance of a person's community toward the person's behaviors. Hwang (2008) opined that internal influence (exerted by family and friends) is more important than external influence (exerted by the media). The more people identify themselves with group preferences, the higher the degree of influence of social norms exerted on their opinions and behaviors. Based on the aforementioned arguments, we proposed Hypothesis 7 as follows:

H7: Social norms have a positive and significant influence on tenant loyalty.

\section{Research design}

\subsection{Conceptual framework}

In this study, the technical dimension of service quality, the functional dimension of service quality, attitudes, perceived behavioral control, and social norms were set as exogenous latent variables in a structural equation model (SEM); while tenant satisfaction and tenant loyalty were set as endogenous latent variables. The structural casual relationships between the seven latent variables were analyzed. Covariance-based SEM (CB-SEM) is used for test validation purposes and requires normally distributed data as well as a large sample size. By contrast, partial least squares SEM (PLS-SEM) is used for exploratory purposes and does not require normally distributed data or a large sample size. According to Reinartz et al. (2009), CB-SEM is more consistent and accurate than PLS-SEM when the sample size is larger than 250. Moreover, Sarstedt et al. (2016) concurred that the bias between CB-SEM and PLSSEM is marginal when the sample size is 250 , and this bias is further reduced with a larger sample size. Since the number of observations in this study was 300, CB-SEM was used. The conceptual framework of this study is shown in Figure 1. 


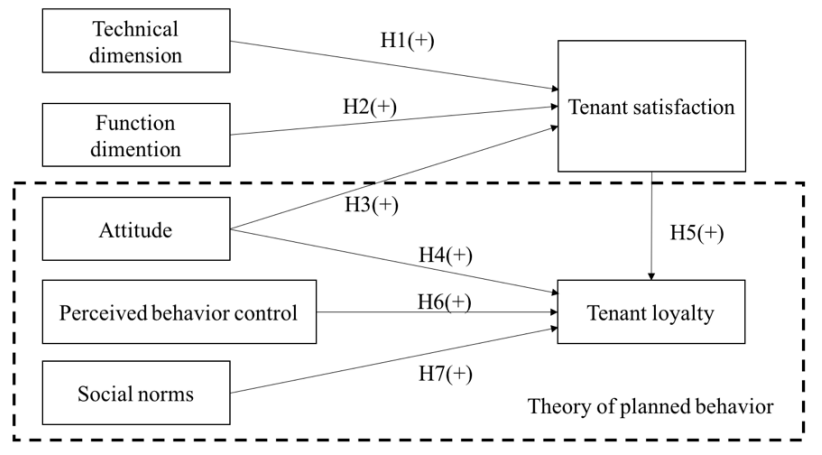

Figure 1. Research framework

\subsection{Questionnaire design}

The questionnaire in this study comprises two sections. The first section contains the participants' basic data, including their gender, age, marital status, education level, occupation, and tenancy period. The second section consists of items pertaining to the variables of the technical dimension, the functional dimension, attitudes, tenant satisfaction, tenant loyalty, perceived behavioral control, and social norms. Items related to the technical dimension were designed according to the studies of Adnan et al. (2012) and Hung and Chang (2002). There were eight items equally distributed in four sub-constructs: monetary performance (rental); tenancy features (compliance to the law and relevant housing regulations); building features, services, and management (housing building management); and agglomeration (close to main roads). Items related to the functional dimension were designed according to the studies of Flint et al. (2011) and Chen and Shiu (2016). There were four items equally distributed in two sub-constructs: proactive customer orientation and responsive customer orientation. Items related to attitudes were designed according to the studies of Ajzen and Fishbein (1980) and Taylor and Todd (1995b, 1995c). There were four items distributed in two sub-constructs: behavioral attitudes and object-based attitudes.

Items related to tenant satisfaction were designed according to the studies of Onibokun (1974); Satsangi and Kearns (1992); and Chen and Shiu (2016). There were six items distributed in four sub-constructs: service contents, price of service, product quality, and customer complaints. Items related to tenant loyalty were designed according to the studies of Onibokun (1974) and Chen and Shiu (2016). There were four items distributed in two sub-constructs: attitudinal loyalty and behavioral loyalty. Items related to perceived behavioral control were designed according to the studies of Ajzen (1991), Taylor and Todd (1995a), and Liu and $\mathrm{Wu}$ (2007). There were four items distributed in two sub-constructs: attitudinal loyalty and behavioral loyalty. Items related to social norms were designed according to the study of Cialdini and Goldstein (2004). There were three items distributed in three sub-constructs: injunctive norms, personal norms, and reciprocity norm The Likert 5-point scale was utilized in the questionnaire, with the level of agreement being divided into five levels of strongly disagree, disagree, neutral, agree, and strongly agree, with each level carrying 1 to 5 points. The authors designed the questionnaire after discussing with university students and collaborated to administer it to the participants. Further details on the items and their references are shown in Table 1.

Table 1. Questionnaire items and reference sources

\begin{tabular}{|c|c|c|c|}
\hline $\begin{array}{l}\text { Measurement } \\
\text { aspect }\end{array}$ & \multicolumn{2}{|r|}{ Questionnaire item } & $\begin{array}{l}\text { Reference } \\
\text { source }\end{array}$ \\
\hline \multirow{8}{*}{$\begin{array}{l}\text { Technical } \\
\text { dimension }\end{array}$} & \multirow{2}{*}{$\begin{array}{l}\text { Monetary performance } \\
\text { (rental) }\end{array}$} & 1. To me, a lower rental would increase my desire to rent & \multirow{4}{*}{$\begin{array}{l}\text { Adnan et al. } \\
(2012)\end{array}$} \\
\hline & & $\begin{array}{l}\text { 2. To me, rental is a salient factor that has to be taken into account } \\
\text { when renting a house }\end{array}$ & \\
\hline & \multirow{2}{*}{$\begin{array}{l}\text { Tenancy features } \\
\text { (compliance with } \\
\text { the law and relevant } \\
\text { housing regulations) }\end{array}$} & $\begin{array}{l}\text { 1. I feel that the tenancy agreement of the house I am renting right } \\
\text { now guarantees my rights }\end{array}$ & \\
\hline & & 2. I feel that tenancy agreements bound by the law guarantee my rights & \\
\hline & \multirow{2}{*}{$\begin{array}{l}\text { Building features, } \\
\text { services, and } \\
\text { management (housing } \\
\text { building management) }\end{array}$} & $\begin{array}{l}\text { 1. To me, it is important for a housing building to have excellent } \\
\text { public safety and entrance security management }\end{array}$ & \multirow{2}{*}{$\begin{array}{l}\text { Hung and } \\
\text { Chang (2002); } \\
\text { Adnan et al. } \\
(2012)\end{array}$} \\
\hline & & $\begin{array}{l}\text { 2. To me, it is important for a housing building to have excellent } \\
\text { public sanitation and landscape management }\end{array}$ & \\
\hline & \multirow[t]{2}{*}{$\begin{array}{l}\text { Agglomeration (close } \\
\text { to main roads) }\end{array}$} & $\begin{array}{l}\text { 1. To me, it is important for a housing building to located within the } \\
\text { vicinity of main roads }\end{array}$ & \multirow[t]{2}{*}{$\begin{array}{l}\text { Adnan et al. } \\
(2012)\end{array}$} \\
\hline & & $\begin{array}{l}\text { 2. I feel that the house I am renting right now has convenient } \\
\text { transportation access }\end{array}$ & \\
\hline \multirow{4}{*}{$\begin{array}{l}\text { Functional } \\
\text { dimension }\end{array}$} & \multirow{2}{*}{$\begin{array}{l}\text { Proactive customer } \\
\text { orientation }\end{array}$} & 1. I feel that my landlord cares about my quality of living & \multirow{4}{*}{$\begin{array}{l}\text { Flint et al. } \\
(2011) ; \text { Chen } \\
\text { and Shiu (2016) }\end{array}$} \\
\hline & & $\begin{array}{l}\text { 2. I feel that my landlord is able to respond to my requests in a timely } \\
\text { manner }\end{array}$ & \\
\hline & \multirow[t]{2}{*}{$\begin{array}{l}\text { Responsive customer } \\
\text { orientation }\end{array}$} & $\begin{array}{l}\text { 1. I feel that my landlord utilizes more diverse means of } \\
\text { communication to contact me }\end{array}$ & \\
\hline & & 2. I feel that my landlord maintains good interactions with me & \\
\hline
\end{tabular}


End of Table 1

\begin{tabular}{|c|c|c|c|}
\hline $\begin{array}{l}\text { Measurement } \\
\text { aspect }\end{array}$ & \multicolumn{2}{|r|}{ Questionnaire item } & $\begin{array}{l}\text { Reference } \\
\text { source }\end{array}$ \\
\hline \multirow[t]{4}{*}{ Attitudes } & \multirow[t]{3}{*}{ Behavioral attitudes } & 1. I feel that my tenancy has positive effects on me & \multirow{4}{*}{$\begin{array}{l}\text { Ajzen and } \\
\text { Fishbein } \\
\text { (1980); Taylor } \\
\text { and Todd } \\
(1995 b, 1995 c)\end{array}$} \\
\hline & & 2. I feel that the experience of renting my house is enjoyable & \\
\hline & & 3. I feel that I am satisfied with the quality of the rented house & \\
\hline & Object-based attitudes & 1. I feel that the house I am renting now can enhance my self-worth & \\
\hline \multirow{6}{*}{$\begin{array}{l}\text { Tenant } \\
\text { satisfaction }\end{array}$} & \multirow[t]{2}{*}{ Service contents } & 1. I feel satisfied with the overall service of my landlord & \multirow{6}{*}{$\begin{array}{l}\text { Onibokun } \\
\text { (1974); Satsangi } \\
\text { and Kearns } \\
\text { (1992); Chen } \\
\text { and Shiu (2016) }\end{array}$} \\
\hline & & $\begin{array}{l}\text { 2. I feel satisfied to know that my landlord is willing to help solve my } \\
\text { problems }\end{array}$ & \\
\hline & Price of service & $\begin{array}{l}\text { 1. I feel satisfied to know that my landlord does not increase the rent } \\
\text { arbitrarily }\end{array}$ & \\
\hline & Product quality & 1. I feel satisfied with the facilities provided in the rented house & \\
\hline & \multirow[t]{2}{*}{ Customer complaints } & 1. I feel satisfied to know that the landlord cares about my rights & \\
\hline & & $\begin{array}{l}\text { 1. I feel satisfied to know that the landlord is able to address my } \\
\text { complaints in a timely manner }\end{array}$ & \\
\hline \multirow[t]{3}{*}{ Tenant loyalty } & \multirow[t]{2}{*}{ Attitudinal loyalty } & $\begin{array}{l}\text { 1. I am willing to retain my tenancy if my landlord does not increase } \\
\text { the rent arbitrarily }\end{array}$ & \multirow{3}{*}{$\begin{array}{l}\text { Oliver (1997); } \\
\text { Chen and Shiu } \\
(2016)\end{array}$} \\
\hline & & 2. I would recommend my landlord's houses to other potential tenants & \\
\hline & Behavioral loyalty & 1. If my tenancy ends soon, I am willing to retain it & \\
\hline \multirow{4}{*}{$\begin{array}{l}\text { Perceived } \\
\text { behavioral } \\
\text { control }\end{array}$} & \multirow[t]{3}{*}{ Perceived self-efficacy } & 1. I am able to keep up with tenancy-related information & \multirow{3}{*}{$\begin{array}{l}\text { Ajzen (1991); } \\
\text { Taylor and } \\
\text { Todd (1995a) }\end{array}$} \\
\hline & & 2. I am capable of renting a house & \\
\hline & & 3. I have full control of whether I want to rent a house & \\
\hline & Perceived convenience & $\begin{array}{l}\text { 1. The house I am renting right now is highly accessible to my } \\
\text { workplace }\end{array}$ & $\begin{array}{l}\text { Liu and } \mathrm{Wu} \\
(2007)\end{array}$ \\
\hline \multirow[t]{3}{*}{ Social norms } & Injunctive norms & $\begin{array}{l}\text { 1. I feel that the opinions of others would influence my assessment of } \\
\text { a house I wish to rent }\end{array}$ & \multirow{3}{*}{$\begin{array}{l}\text { Cialdini and } \\
\text { Goldstein } \\
(2004)\end{array}$} \\
\hline & Personal norms & 1. I feel that one does not need to buy a house throughout their life & \\
\hline & Reciprocity norm & $\begin{array}{l}\text { 1. The landlord treats me well and therefore I am willing to maintain } \\
\text { the surroundings of the house I am renting }\end{array}$ & \\
\hline
\end{tabular}

\subsection{Sampling method and data collection}

The participants consisted of tenants residing in nine administrative districts (Cianjhen, Tsoying, Sanmin, Lingya, Cianjin, Sinsing, Yancheng, Fongshan, and Gushan) in Kaohsiung City. The 2010 merge of Kaohsiung City and Kaohsiung County into a special municipality resulted in 38 districts (consisting of 11 districts from the former and 27 cities and rural/urban townships from the latter). In this study, eight of the 11 former Kaohsiung City districts (the relatively less vibrant districts of Cijin, Nanzih, and Siaogang were excluded) alongside the former country seat of Fongshan City (now a district) were included for analysis. The former Kaohsiung City was Taiwan's second most populous city, and is currently the third largest city following the merge. The city has a population of 2.76 million in 2021, and is a bustling commercial, tourism and service industry hub. Moreover, the author of this study is employed in nearby Pingtung County, and hence, considering the bustling commercial scene and easy accessibility of transportation services, Kaohsiung City was selected as the study area. The sample size must be considered dur- ing sampling, as it affects the accuracy of the estimated results. We assumed a permissible error of 0.05 and a significance level $(\alpha)$ of $10 \%$, that is, a required sample size of 271 at a $90 \%$ confidence interval. The total number of valid questionnaires in this study was 300 , which exceeded the required observed value of 271 . The researchers administered a questionnaire to each participant in person, who were recruited via convenience sampling. During the process, the six-person research team was split into three teams of two. Each team separately visited housing buildings and apartments in the eight abovementioned districts and explained the details of the research to the security personnel. After the tenants have returned, the researchers kindly requested them to fill out the questionnaire without coercion or interference, so as to allow them to subjectively express their thoughts and feelings. A total of 315 questionnaires were administered from June 1, 2019 to June 30,2019 . All of the questionnaires were recovered. After removing 15 invalid responses (incomplete or had duplicate responses to items), there were 300 valid responses, indicating an effective recovery rate of $95.2 \%$. 


\section{Descriptive statistics, reliability, and validity of sample data}

\subsection{Descriptive statistics of samples}

Among the valid samples, men accounted for $46.3 \%$ (139 participants) of respondents and women accounted for $53.7 \%$ (161 participants) of respondents. A majority (151 participants, $50.3 \%$ ) of the participants were aged between 21 to 30 years; followed by 85 participants (28.4\%) in the 31-40 years age group; and then 43 participants $(14.3 \%)$ in the $41-50$ years age group. The mean age of the respondents was 33 years. In terms of marital status, there were 204 unmarried respondents (68\%), 89 married respondents (30\%), and seven others (2\%). In terms of education level, university-level respondents (including fourand two-year programs) accounted for the highest proportion of respondents at $60 \%$ (179 participants); followed by those who hold a master's degree (42 participants, $14 \%$ ); those with high school (vocational) education or below (40 participants, 13\%); those with junior college-level education (32 participants, 11\%), and then those who hold a doctorate degree (seven participants, $2 \%$ ). In terms of occupation, those in the line of agriculture/industrial/commerce accounted for 41\% (121 participants); followed by military officers/civil servants/teachers, who accounted for 30\% (90 participants); those with other occupations, who accounted for 78 participants (26\%); and housekeepers who accounted for 11 participants (4\%). In terms of tenancy period, 80 participants $(27 \%)$ had been renting for less than a year; 140 participants (47\%) had been renting for one to three years (the majority); 45 participants (15\%) had been renting for four to six years; 21 participants $(7 \%)$ had been renting for seven to nine years; and 14 participants (5\%) had been renting for over ten years. The characteristics of the sample structure are as follows: there was a higher proportion (53.7\%) of female respondents; the mean age of the respondents was 33 years; most of them were unmarried; most of them had graduated from university; most of them were in the line of agriculture/industrial/commerce, and most of them had been renting their house for one to three years. The correlation coefficient between the two measurement variables of Technical dimension and the four measurement variables of Tenant satisfaction is between $0.34-0.76$. The correlation coefficient between the four measurement variables of Functional dimension and the four measurement variables of Tenant satisfaction is between $0.14-0.53$. The correlation coefficient between the four measurement variables of Tenant satisfaction and the two measurement variables of Tenant loyalty is between $0.46-0.58$. The correlation coefficient between the three measurement variables of Social norms and the two measurement variables of Tenant loyalty is between 0.17-0.58 (A correlation matrix between the measured variables is provided in Appendix Table A1).

Single source bias occurs when data is collected from the same participants. As the participants provide their responses, their cognitive schema would increase their ten- dency to conceptualize the information. Thus, the similarities in their interpretations would inflate the correlation coefficients between the constructs in their responses. This problem is particularly heightened when the items are positively worded and are measured on a five-point Likert scale (Avolio et al., 1991). One method for redressing this problem is to separate the sources, by which researchers employed paired comparison questionnaires for data collection (Chung \& Su, 2014). For instance, in studies pertaining to the relationship between authentic leadership and job performance, employees were asked to complete an authentic leadership questionnaire, while their supervisors were asked to complete their subordinates job performance questionnaire. Another method would be reverse coding. For questionnaires that consist exclusively of positively worded items, reverse worded items could be integrated into the list. In this way, the respondent's level of attention can be monitored and their attempts to provide responses in a consistent manner can be reduced (Peng et al., 2006). While these two methods can mitigate single source bias, they are unable to completely eliminate common method variance (CMV), as single source bias is merely a problem derived from CMV. In this study, Harman's single factor test was used to examine whether CMV between the variables had significantly affected the results (Podsakoff \& Organ, 1986). It must be noted, however, that this approach is regarded as one for examining the severity of CMV, and it cannot be used directly for eliminating CMV (Peng et al., 2006).

\subsection{Reliability and validity analysis}

In addition to a reliability analysis, researchers must also perform a validity analysis on a questionnaire. This analysis tests the content validity and construct validity of the questionnaire. In terms of content validity, the questionnaire primarily explored tenancy and was designed based on tenancy-related studies. The researchers first discussed the contents with relevant professionals and then revised the items and meanings. The questionnaire in this study was determined to have a certain level of content validity. Next, construct validity tests whether the questionnaire constructs are able to capture actual situations (Chang, 2001). In this study, standardized factor loadings were used as standard for measuring construct validity. All the factor loadings of the items attained a level of significance and hence the questionnaire was determined to have construct validity. In addition, the convergent validity and the discriminant validity of the questionnaire were tested. (1) Convergent validity is based on the standardized factor loadings of each construct item. Hair et al. (2006) stated that the standardized factor loadings of each construct should be greater than 0.5 ; a higher average variance extracted (AVE) of a construct represents a stronger reliability, as well as higher convergent validity. With the exception of social norms, which had a standardized factor loading of 0.341 , all the other constructs had a standardized factor loading that exceeds 0.5 and attained a level 
of significance, which indicates that most of the constructs had convergent validity (see Table 3). (2) Discriminant validity checks for correlation between two different constructs. This study performed discriminant validity analysis according to the recommendations of Anderson and Gerbing (1988). In a correlation analysis, discriminant validity is said to be present between two different constructs when the correlation between the constructs is very low. The square root of the AVE of each construct should be greater than the coefficient of correlation between the constructs (Hair et al., 1998). Based on Table 3, the square root of the AVE of each construct ranged from
0.446 to 0.948 . With the exception of tenant loyalty and social norms, the square roots of the AVE of the other constructs were greater than their coefficients of correlation. This result shows that most of the constructs had met the aforementioned criterion and hence the questionnaire was determined to have discriminant validity. The HTMT is used in research to assess discriminant validity. Researchers have highlighted its high sensitivity and specificity, as a HTMT smaller than 0.85 indicates stringent discriminant validity between each latent variable (Henseler et al., 2015). As shown in Table 4, this criterion has been met, and hence this study has excellent discriminant validity.

Table 2. Analysis of reliability, factor loading, and average value extracted of the questionnaire

\begin{tabular}{|c|c|c|c|c|c|c|c|}
\hline Variables & $\begin{array}{l}\text { Factor loading } \\
\text { (unstandardized) }\end{array}$ & $\begin{array}{l}\text { Factor loading } \\
\text { (standardized) }\end{array}$ & $\begin{array}{c}\text { Error } \\
\text { variance }\end{array}$ & $\begin{array}{l}\text { Measured } \\
\text { variable } \\
\text { reliability }\end{array}$ & $\begin{array}{l}\text { Composite } \\
\text { reliability } \\
\text { (CR) }\end{array}$ & $\begin{array}{c}\text { Average } \\
\text { variance } \\
\text { extracted } \\
(\mathrm{AVE})\end{array}$ & $\begin{array}{c}\text { Structural } \\
\text { equation } \\
\text { assessment } R^{2}\end{array}$ \\
\hline Technical dimension & & & & & 0.795 & 0.582 & - \\
\hline $\begin{array}{l}\text { Monetary } \\
\text { performance }\end{array}$ & 1.000 & 0.332 & 0.364 & 0.110 & & & \\
\hline Agglomeration & $1.740^{* *}$ & $0.522^{\star *}$ & 0.365 & 0.272 & & & \\
\hline Building management & $2.341^{\star *}$ & $0.734^{* *}$ & 0.212 & 0.538 & & & \\
\hline Tenancy features & $2.161^{\star *}$ & $0.628^{\star *}$ & 0.323 & 0.394 & & & \\
\hline Functional dimension & & & & & 0.946 & 0.898 & - \\
\hline $\begin{array}{l}\text { Proactive } \\
\text { Responsive }\end{array}$ & $\begin{array}{c}1.000 \\
0.901^{\star *}\end{array}$ & $\begin{array}{c}0.981 \\
0.870^{* *}\end{array}$ & $\begin{array}{l}0.025 \\
0.170\end{array}$ & $\begin{array}{l}0.963 \\
0.756\end{array}$ & & & \\
\hline Attitudes & & & & & 0.920 & 0.853 & - \\
\hline Behavioral attitudes & 1.000 & 1.103 & 0.001 & 1.216 & & & \\
\hline Object-based attitudes & $0.920^{* *}$ & $0.796^{* *}$ & 0.316 & 0.634 & & & \\
\hline Tenant satisfaction & & & & & 0.913 & 0.731 & 0.658 \\
\hline Service contents & 1.000 & 0.861 & 0.128 & 0.742 & & & \\
\hline Price of service & $0.689^{* *}$ & $0.551^{\star *}$ & 0.399 & 0.303 & & & \\
\hline Product quality & $0.926^{\star \star}$ & $0.742^{\star *}$ & 0.257 & 0.550 & & & \\
\hline Customer complaints & $1.081^{\star *}$ & $0.900^{\star *}$ & 0.101 & 0.809 & & & \\
\hline Tenant loyalty & & & & & 0.913 & 0.841 & 0.550 \\
\hline Attitudinal loyalty & 1.000 & 0.914 & 0.091 & 0.836 & & & \\
\hline Behavioral loyalty & $1.014^{\star *}$ & $0.839^{\star \star}$ & 0.201 & 0.704 & & & \\
\hline $\begin{array}{l}\text { Perceived behavioral } \\
\text { control }\end{array}$ & & & & & 0.797 & 0.665 & - \\
\hline Perceived self-efficacy & 1.000 & 0.853 & 0.147 & 0.727 & & & \\
\hline Perceived convenience & $1.018^{\star \star}$ & $0.687^{\star \star}$ & 0.456 & 0.471 & & & \\
\hline Social norms & & & & & 0.401 & 0.199 & - \\
\hline Injunctive norms & 1.000 & 0.312 & 0.629 & 0.097 & & & \\
\hline Personal norms & $1.660^{* *}$ & $0.341^{\star *}$ & 1.424 & 0.116 & & & \\
\hline Reciprocity norm & $2.006^{* *}$ & $0.631^{\star *}$ & 0.413 & 0.398 & & & \\
\hline
\end{tabular}


Table 3. Correlation matrix of latent variables

\begin{tabular}{|l|c|c|c|c|c|c|c|}
\hline & $\begin{array}{c}\text { Technical } \\
\text { dimension }\end{array}$ & $\begin{array}{c}\text { Functional } \\
\text { dimension }\end{array}$ & Attitudes & $\begin{array}{c}\text { Tenant } \\
\text { satisfaction }\end{array}$ & $\begin{array}{c}\text { Tenant } \\
\text { loyalty }\end{array}$ & $\begin{array}{c}\text { Perceived } \\
\text { behavioral } \\
\text { control }\end{array}$ & $\begin{array}{c}\text { Social } \\
\text { norms }\end{array}$ \\
\hline Technical dimension & 0.763 & & & & & & \\
\hline Functional dimension & 0.010 & 0.948 & & & & & \\
\hline Attitudes & 0.001 & 0.001 & 0.924 & & & & \\
\hline Tenant satisfaction & 0.283 & 0.731 & 0.217 & 0.855 & & & \\
\hline Tenant loyalty & 0.105 & 0.271 & 0.204 & 0.398 & 0.917 & & \\
\hline Perceived behavioral control & 0.001 & 0.001 & 0.001 & 0.001 & 0.163 & 0.815 & \\
\hline Social norms & 0.001 & 0.001 & 0.001 & 0.001 & 0.584 & 0.001 & 0.446 \\
\hline
\end{tabular}

Note: The diagonal elements shown in this matrix are the square roots of the constructs' AVE.

Table 4. HTMT value of latent variables

\begin{tabular}{|l|c|c|c|c|c|c|}
\hline & $\begin{array}{c}\text { Technical } \\
\text { dimension }\end{array}$ & $\begin{array}{c}\text { Functional } \\
\text { dimension }\end{array}$ & Attitudes & $\begin{array}{c}\text { Tenant } \\
\text { satisfaction }\end{array}$ & $\begin{array}{c}\text { Tenant } \\
\text { loyalty }\end{array}$ & $\begin{array}{c}\text { Perceived } \\
\text { behavioral } \\
\text { control }\end{array}$ \\
\hline Functional dimension & 0.575 & & & & & \\
\hline Attitudes & 0.612 & 0.703 & & & & \\
\hline Tenant satisfaction & 0.727 & 0.802 & 0.665 & & & \\
\hline Tenant loyalty & 0.656 & 0.626 & 0.573 & 0.735 & & \\
\hline Perceived behavioral control & 0.721 & 0.561 & 0.604 & 0.676 & 0.586 & \\
\hline Social norms & 1.027 & 0.785 & 0.745 & 0.843 & 0.870 & 0.700 \\
\hline
\end{tabular}

This study verified whether the data between the variables was distributed normally by assuming that the sample had a multivariate normal distribution. The test results indicated that Mardia's multivariate kurtosis coefficient was 108.472 and the critical ratio (CR) was 33.255. A CR greater than 1.96 means that the variables are not normally distributed. The test results suggest the absence of multivariate normal distribution. Therefore, we assumed that the data was distributed normally before using the maximum likelihood (ML) approach. According to Boomsma and Hoogland (2001), under non-normal distribution conditions, ML offers better statistical benefits for larger models with more than six observations. Kline (1998) pointed out that a satisfactory level is achieved when the absolute values of skewness and kurtosis do not exceed 3 and 8, respectively. Moreover, a kurtosis greater than 20 indicates considerable severity. The absolute values of skewness and kurtosis were less than 3 and 8 in this study. In practice, each estimation method has its own limitations. Since the kurtoses of the variables in this study were rather small, ML estimation was used (Please refer to Lee (2012) for further information).

\section{Empirical results and discussion}

The parameters in this study were estimated by the maximum likelihood (ML) method. The fit of the conceptual framework model was first assessed, after which an analysis of the linear structural model was performed.

\subsection{Questionnaire design}

To assess the fit of the conceptual framework model, three evaluation criteria proposed by Bagozzi and Yi (1988) were used in this study, namely preliminary fit criteria, fit of internal structure of the model, and overall model fit.

(1). Preliminary fit criteria

Preliminary fit criteria state that the measured error of the indicators must have positive values; the standardized factor loadings must not be too high or low (between 0.50 to 0.95 ); and the values must attain a level of significance. Preliminary fit criteria is used to check for errors in the model and detect identification or input problems (Chen, 2003). According to Table 2, the factor loadings of the measured variables ranged from 0.341 to 0.900 . The values of the two structural equations in this study were 0.658 and 0.550 , respectively, which indicated an acceptable preliminary fit.

(2). Fit of internal structure of the model

According to Bagozzi and Yi (1988), three approaches can be used to assess the goodness-of-fit of a model's internal structure - the individual item reliability of each observed variable; the composite reliability (CR) of each latent variable; and the average variance extracted (AVE) of each latent variable is described as follows: The reliability of each individual item is used to assess the construct reliability of measured variables on their corresponding latent variables, to validate if a factor loading was greater than 0.5 , and to check the statistical significance of each 
loading. With the exception of that of personal norms, all the other factor loadings exceeded 0.50 and attained a level of significance (see Table 2). The CR of a latent variable is an aggregate of the reliabilities of its measured variables. It represents the internal consistency of construct indicators, as the high CR of an indicator reflects its high consistency. A CR greater than 0.60 is considered acceptable (Fornell \& Larcker, 1981). In this study, with the exception of that of social norms, all the CRs of the variables exceeded the acceptable cutoff point of 0.60 . The AVE of a latent variable is a measure of the explanatory power of the latent variable on all measured variables. A high AVE indicates that the latent variable has a high reliability and convergent validity. An AVE greater than 0.50 is considered acceptable (Fornell \& Larcker, 1981). According to Table 2, with the exception of social norms (which had an AVE of only 0.199), all of the other variables had AVEs greater than 0.50 , which indicates that the internal consistency of the scale was desirable. The low coefficients of correlation of the three variables in the Social Norms construct could be the main reason for the low composite reliability value and AVE result for Social norms.

\section{(3). Overall model fit}

In this study, the overall model fit was assessed by means of absolute fit measures, incremental fit measures, and parsimonious fit measures (Chiu, 2009; Chen \& Wang, 2011). The fit of a model cannot be determined through a single indicator or criterion, and hence the test results of the overall model fit must be taken into account. Absolute fit indices validate the goodness of the fit of the theoretical model and the sample data. An overly large sample size would also increase the values and could easily lead to the rejection of the null hypothesis, which causes the inconsistent distribution of the sample data and the theoretical model (i.e., the conceptual framework of this study). Researchers have suggested that other fit indices, such as the Chi-square/degree of freedom ratio, must be taken into account when determining the goodness-of-fit of a model (Hair et al., 1998). In general, the higher the ra- tio, the better the fit of the model, with the maximum value being three (some studies have stated that five or seven is acceptable too). Other fit indices include goodness-of-fit index, (GFI), root mean square residual (RMR), and root mean square error of approximation (RMSEA). Based on Table 5, the chi-square statistic of this study was 904.035 $(p=0.001)$, which indicates that the conceptual framework model had some differences with the sample data. The $\chi^{2}$ / df ratio was 6.235; the GFI was 0.724; the RMR was 0.203 ; and the RMSEA was 0.132 , which were all within the acceptable thresholds. Incremental fit indices compare the level of the fit between the theoretical model and the test data. Commonly-used incremental fit indices include the adjusted goodness-of-fit index (AGFI), the normed fit index (NFI), and the comparative fit index, (CFI). In this study, the AGFI, NFI, and CFI was $0.639,0.753$, and 0.783 , respectively, and were within their acceptable ranges despite not reaching the standard. Parsimonious fit indices measure the parsimony of a theoretical model, so as to understand if the model was "too fit" due to a high number of coefficients (Hair et al., 1998). The parsimony normed fit index (PNFI) and the parsimony goodness-of-fit index (PGFI) of this study was 0.639 and 0.664 , respectively, and both were larger than 0.50 . Consolidating the abovementioned results, the overall goodness-of-fit, incremental fit, and parsimonious fit indices of the model were acceptable. This shows that the goodness-of-fit of this study's conceptual framework model was acceptable.

\subsection{Analysis of linear structure model and discussion}

The empirical results are presented in Table 6 and Figure 2 . The estimated coefficient of the technical dimension on tenant satisfaction was 0.281 and attained a $1 \%$ level of significance. This shows that the technical dimension had a positive and significant effect on tenant satisfaction. The stronger the tenants' perceived technical dimension, the higher their perceived satisfaction. Petty

Table 5. Goodness-of-fit indices of the conceptual framework model developed in this study

\begin{tabular}{|l|c|c|c|}
\hline \multicolumn{2}{|c|}{ Test statistics } & Acceptable value & Test result \\
\hline \multirow{4}{*}{ Absolute fit measures } & $\chi^{2}(p$-value $)$ & 904.035 & 0.001 \\
\cline { 2 - 4 } & $\chi^{2} / d f$ & $<5$ & 6.235 \\
\cline { 2 - 4 } & GFI & Smaller values suggest a better fit & 0.724 \\
\cline { 2 - 4 } & RMR & Smaller values suggest a better fit, preferably $<0.05$ & 0.203 \\
\cline { 2 - 4 } Incremental fit measures & RMSEA & $>0.90$ & 0.132 \\
\cline { 2 - 4 } & AGFI & $>0.90$ & 0.639 \\
\cline { 2 - 4 } & NFI & $>0.90$ & 0.753 \\
\hline Parsimonious fit measures & CFI & $>0.50$ & 0.639 \\
\cline { 2 - 4 } & PGFI & $>0.50$ & 0.664 \\
\hline
\end{tabular}


Table 6. Estimation results of the linear structural equation model

\begin{tabular}{|l|l|c|c|c|c|}
\hline \multicolumn{1}{|c|}{ Hypothesis } & \multicolumn{1}{|c|}{ Inter-variable relationship } & $\begin{array}{c}\text { Estimated } \\
\text { coefficient }\end{array}$ & $\begin{array}{c}\text { Standard } \\
\text { error }\end{array}$ & $t$-value & $p$-value \\
\hline Hypothesis 1 & Technical dimension $\rightarrow$ Tenant satisfaction & 0.281 & 0.210 & 3.822 & $0.001^{\star *}$ \\
\hline Hypothesis 2 & Functional dimension $\rightarrow$ Tenant satisfaction & 0.734 & 0.039 & 14.206 & $0.001^{\star *}$ \\
\hline Hypothesis 3 & Attitudes $\rightarrow$ Tenant satisfaction & 0.199 & 0.038 & 3.987 & $0.001^{\star *}$ \\
\hline Hypothesis 4 & Attitudes $\rightarrow$ Tenant loyalty & 0.065 & 0.040 & 1.387 & 0.165 \\
\hline Hypothesis 5 & Tenant satisfaction $\rightarrow$ Tenant loyalty & 0.398 & 0.064 & 6.953 & $0.001^{* *}$ \\
\hline Hypothesis 6 & Perceived behavioral control $\rightarrow$ Tenant loyalty & 0.172 & 0.081 & 2.299 & $0.021^{\star}$ \\
\hline Hypothesis 7 & Social norms $\rightarrow$ Tenant loyalty & 0.589 & 0.429 & 3.593 & $0.001^{\star *}$ \\
\hline
\end{tabular}

Note: ${ }^{*}$ indicates $p<0.5 ;{ }^{* *}$ indicates $p<0.01$.

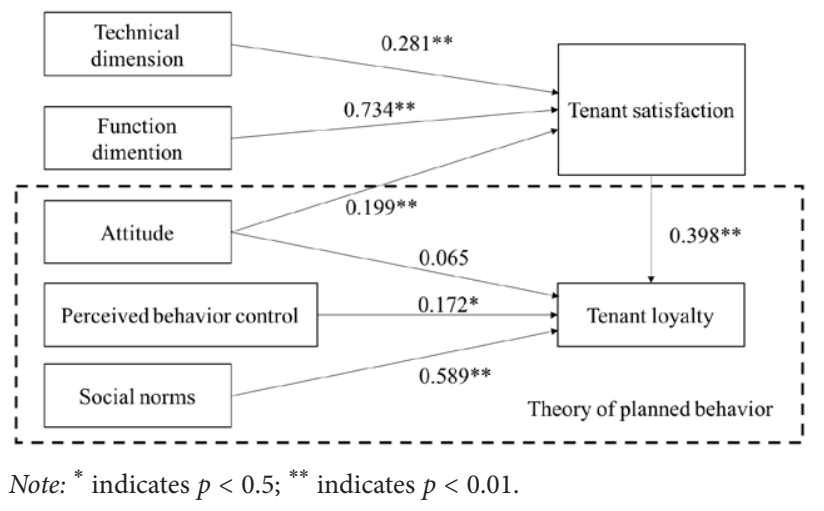

Figure 2. The theoretical structural equation model presented with standardized coefficients

and Wegener (1999) proposed that the technical dimension plays a salient role in tenant satisfaction. Muhlebach (1998) pointed out that enhancing the building's interior and exterior appearances would increase tenants' willingness to retain their tenancy. Hung and Chang (2002) demonstrated that management and maintenance companies with professional management experience and technical capabilities can enhance residents' satisfaction through several methods, such as implementing entrance security, maintaining environmental sanitation, strengthening security patrols, quick repair of malfunctioned mechanical and electrical equipment, and improving the quality of living environments. Residents would feel that the additional costs of improving their living environment are worthwhile. Kirkpatrick and Tarasuk (2011) pointed out that housing products, accessibility, features of the public sector, and environmental features are factors that influence customers' satisfaction of living. According to AppelMeulenbroek (2008), parking facilities, locational factors (close to the city center and public infrastructure), and accessibility exert a positive influence on tenant satisfaction. The empirical results are in support of Hypothesis 1.

The estimated coefficient of the functional dimension on tenant satisfaction was 0.734 and attained a $1 \%$ level of significance. This shows that the functional dimension had a positive and significant effect on tenant satisfaction.
The stronger the tenants' perceived functional dimension, the higher their perceived satisfaction. The functional dimension encompasses the level of service provided to customers, that is the customers' perceptions of the interactions that occurred during the service delivery process (Kang, 2006). Tenants nowadays pay more attention to the level of service received. Hence, in order to maintain their competitiveness, it is important for rental companies to listen and respond to the need, opinions, and expectations of tenants, so as to achieve optimal management (Muhlebach, 1998). If the level of service provided by the building management is lower than the residents' expected level, then residents would have lower satisfaction, which could prompt them to move to better places (Tsang, 2009). Successful rental companies regard tenants as valuable customers, and identifying customers' preferences can help these companies provide excellent services as well as customized products (Kennedy \& Schneider, 2000). Therefore, there is a need to understand the essence of customer satisfaction in a deeper way, so as to elucidate the long-term development of landlord-tenant business relations (Tikkanen \& Alajoutsijarvi, 2002). In other words, the functional dimension has a salient and significant influence on tenant satisfaction. The empirical results are in support of Hypothesis 2.

The estimated coefficient of attitudes on tenant satisfaction was 0.199 and attained a $1 \%$ level of significance. This shows that attitudes had a positive and significant effect on tenant satisfaction. The stronger the tenants' perceived benefits of their rented house, the higher their perceived satisfaction. One's attitudes toward a particular brand are important as such attitudes reflect one's strong support in terms of belief and affection. Lercher (2003) and Bonaiuto et al. $(2003,2006)$ remarked that behavioral attitudes directly and positively influence residents' satisfaction. The empirical results are in support of Hypothesis 3. The estimated coefficient of attitudes on tenant loyalty was 0.065 and did not attain a level of significance. This shows that attitudes did not have a significant effect on tenant loyalty. Loyal tenants have a strong sense of attachment and are highly willing to repeat their purchases (Zins, 2001; Baloglu, 2002). A good attitude is an expression of loyalty and also shows that tenants could develop purchase 
intentions (Smith \& Swinyard, 1983). In practice, housing prices in Taiwan are high, and hence many prospective house buyers resort to renting instead. Some people feel stressed because of the high rental rates. Therefore, even though tenants are satisfied with their rented houses, their attitudes could change because of internal and external environmental changes or rising rental rates. This explains the lack of loyalty in the tenants. This empirical finding closely reflects the situation in Taiwan. Nonetheless, the empirical supports did not support Hypothesis 4 .

The estimated coefficient of tenant satisfaction on tenant loyalty was 0.398 and attained a $1 \%$ level of significance. This shows that tenant satisfaction had a positive and significant effect on tenant loyalty. The stronger the tenants' perceived satisfaction, the higher their perceived loyalty. Our empirical findings are in line with those of Dogge and Smeets (2004). Turel and Serenko (2006) pointed out that customer satisfaction positively influences customers' repurchase behaviors, which serve as an expression of loyalty. Fuentes-Blasco et al. (2014) opined that satisfaction has a salient and positive influence on customer loyalty. Gibler et al. (2014) revealed that tenants who are satisfied with their rented house, landlord, or building management are more likely to retain their tenancy. Hypothesis 5 is supported. The empirical results are in support of Hypotheses 3 and 5 but are not in support of Hypothesis 4. This shows that even though attitudes did not have any direct influences on tenant loyalty, they indirectly influenced tenant loyalty through tenant satisfaction as a mediator.

The estimated coefficient of perceived behavioral control on tenant loyalty was 0.172 and attained a $5 \%$ level of significance. This shows that perceived behavioral control had a significant and positive effect on tenant loyalty, that is personal needs, desires, and exchanged values are associated with loyalty. Ajzen (1991) pointed out that perceived behavioral control is the perceived degree of difficulty of performing a particular behavior. A customer with a strong perceived behavioral control have higher purchase intentions. Gasiorowska (2014) suggested that during the transaction of goods, perceived behavioral control influences a consumer's ability to pay for the goods they have purchased, and purchase intentions are affected by a consumer's ability to pay. Therefore, perceived behavioral control effectively affects purchase intentions. Perceived behavioral control is often regarded as an important indicator for explaining a person's behavioral intentions (Parasuraman, 1997; Parasuraman \& Grewal, 2000). The empirical results are in support of Hypothesis 6. The estimated coefficient of social norms on tenant loyalty was 0.589 and attained a $1 \%$ level of significance. This shows that social norms have a positive and significant influence on tenant loyalty. A tenant's perception of loyalty would be affected when society does not shun their tenancy and the tenant has a good relationship with their landlord. Smith et al. (2007) suggested that people would tend to rely on social norms when they encounter uncertainties. Fishbein and Ajzen (1975) mentioned that social norms are the so- cial normative pressures that one must take into account when performing a particular behavior, that is, whether a person's behaviors were influenced by influential people or groups. Therefore, social norms influence one's behaviors. Smith et al. (2007) suggested that people would tend to rely on social norms when they encounter uncertainties. For instance, when society have different attitudes toward tenancy, tenants would be influenced by social norms. When social norms exert positive influences on the tenants' perception of their rented house, their willingness to stay would be affected as well. The empirical results are in support of Hypothesis 7.

\section{Conclusions and recommendations}

\section{Analysis of linear structure model and discussion}

\section{Theoretical implication}

This study primarily aimed to examine the factors influencing personal behavior on tenant loyalty. The theory of planned behavior (which encompasses attitude, perceived behavioral control, and social norms) served as the basis of this study; and the three variables of the technical dimension, the functional dimension, and tenant satisfaction were incorporated to build a conceptual framework of tenant loyalty. The empirical results showed that the conceptual framework model on tenant loyalty had an acceptable fit, which indicates that the distribution of the sample data was consistent with the theoretical model. The results showed that the technical dimension, the functional dimension, and attitude significantly and positively influenced tenant satisfaction. Tenant satisfaction, perceived behavioral control, and social norms significantly and positively influenced tenant loyalty. With the exception of Hypothesis 4 (attitudes did not have significant effects on tenant loyalty), the hypotheses in this study were supported by the empirical results.

\section{Practical implication}

In terms of policy-related implications, the influence of the functional dimension on tenant satisfaction highlights the importance of proactive customer orientation and responsive customer orientation on tenant satisfaction. In other words, proactive customer orientation is regarded as a value that creates excellence for customers, that is, a landlord cares about their tenants' quality of living and is able to respond to the tenants' responses in a timely manner. Responding to tenants' complaints and needs in a timely manner is a way to show that managers care about tenants. Responsive customer orientation refers to a service provider's ability to effectively respond to the precise needs of customers, that is, a service provider would utilize more diverse means of communication to contact their tenants, maintain good relationships with them, and is able to effectively and quickly respond to the tenants' precise needs.

With regard to the influence of the technical dimension on tenant satisfaction, several factors should be taken 
into account. For instance, a tenancy agreement should guarantee the rights of a tenant according to laws related to tenancy. Rented housing buildings with features, good service (building) management, excellent public safety and entrance security management, good public sanitation and landscapes, located near main roads, and offer convenient transportation also play an important role. Furthermore, lower rentals relatively increase a potential tenant's desire to rent a place. In short, these factors exert important effects on tenant satisfaction.

As Taiwanese citizens' income increases, they have more demands for housing quality, as they desire a house that not only provides shelter, but also emphasize the internal structure, external environmental quality, as well as the quality of the functional dimension. The empirical results of this study suggest that the influence of the functional dimension on tenant satisfaction exceeds that of the technical dimension. This further highlights the salience of proactive customer orientation and responsive customer orientation (which are both components of the functional dimension) on tenant satisfaction. This study indicates that housing rental companies should place more emphasis more on the functional dimension when they plan to rent out a house. They should not only express concern to the tenants' quality of living but also address the tenants' needs in a proactive manner.

\section{Recommendations for future studies}

In this study, data was acquired by means of a questionnaire, in which responses were recorded on a five-point Likert scale. The responses were based on the subjective perceptions of the respondents, and the results are often influenced by their emotions and personal preferences. In order to overcome this shortcoming, the qualitative research approach could be employed as a supplement approach to examine the actual living environments and tenancy agreements of the tenants, as well as their attitudes and satisfaction levels. The supplementary qualitative research approach not only strengthens the contents of a quantitative research, but the data collected through both methods enables investors and consumers to understand trends in the housing rental market, thus enhancing the practicality and credibility of the results. The low coefficients of correlation of the three variables in the Social Norms construct could be the main reason for the low composite reliability value and AVE result for Social norms. In future studies, the operational definition of social norms should be revised, along with its items. In this study, data was collected from tenants living in housing buildings and apartments, but not from those who are renting a townhouse. Therefore, townhouse tenants should be included in future studies, so as to enhance the practicality and the value of the results for relevant studies on the housing rental market. Additionally, previous studies mostly emphasized the housing choices of tenants. Future studies could perform cross-analyses and comparisons between landlord and tenant housing choices, so as to better meet the needs of the rental market as well as to provide a reference for the government to develop robust rentalrelated policies.

\section{References}

Adnan, Y. M., Daud, M. N., \& Razali, M. N. (2012). Property specific criteria for office occupation by tenants of purpose built office buildings in Kuala Lumpur, Malaysia. Property Management, 30(2), 114-128.

https://doi.org/10.1108/02637471211213389

Ajzen, I. (1985). From intention to actions: a theory of planned behavior, action-control: from cognition to behaviour (pp. 1139). Springer. https://doi.org/10.1007/978-3-642-69746-3_2

Ajzen, I. (1987). Attitudes, traits, and actions: dispositional prediction of behavior in personality and social psychology. In Advances in experimental social psychology (Vol. 20, pp. 1-63). Academic Press.

https://doi.org/10.1016/S0065-2601(08)60411-6

Ajzen, I. (1991). The theory of planned behavior. Organizational Behavior and Human Decision Processes, 50(2), 179-211. https://doi.org/10.1016/0749-5978(91)90020-T

Ajzen, I., \& Fishbein, M. (1980). Understanding attitudes and predicting social behavior. Prentice-Hall.

Ajzen, I., \& Madden, T. J. (1986). Prediction of goal-directed behavior: attitudes, intentions, and perceived behavioral control. Journal of Experimental Social Psychology, 22(5), 453-474. https://doi.org/10.1016/0022-1031(86)90045-4

Anderson, J. C., \& Gerbing, D. W. (1988). Structural equation modeling in practice: a review and recommended two-step approach. Psychological Bulletin, 103(3), 411-423. https://doi.org/10.1037/0033-2909.103.3.411

Appel-Meulenbroek, R. (2008). Managing "keep" factors of office tenants to raise satisfaction and loyalty. Property Management, 26(1), 43-55. https://doi.org/10.1108/02637470810848886

Avolio, B. J., Yammarino, F. J., \& Bass, B. M. (1991). Identifying common methods variance with data collected from a single source: an unresolved sticky issue. Journal of Management, 17(3), 571-587. https://doi.org/10.1177/014920639101700303

Bagozzi, R. P., \& Yi, Y. (1988). On the evaluation of structural equation models. Journal of the Academy of Marketing Science, 16(1), 74-94. https://doi.org/10.1007/BF02723327

Baharum, Z. A., Nawawi, A. H., \& Saat, Z. M. (2009). Service quality and property management service: a conceptual framework. Journal of Built Environment, 6(1), 12-34.

Baloglu, S. (2002). Dimensions of customer loyalty: separating friends from wellwishers. The Cornell Hotel and Restaurant Administration Quarterly, 43(1), 47-59.

https://doi.org/10.1016/S0010-8804(02)80008-8

Beverland, M., Farrelly, F., \& Woodhatch, Z. (2004). The role of value change management in relationship dissolution: hygiene and motivational factors. Journal of Marketing Management, 20(9-10), 927-939.

https://doi.org/10.1362/0267257042405295

Blocker, C. P., Flint, D. J., Myers, M. B., \& Slater, S. F. (2011). Proactive customer orientation and its role for creating customer value in global markets. Journal of the Academy of Marketing Science, 39(2), 216-233.

https://doi.org/10.1007/s11747-010-0202-9

Bonaiuto, M., Fornara, F., \& Bonnes, M. (2003). Indexes of perceived residential environment quality and neighborhood attachment in urban environments: a confirmation study on the city of Rome. Landscape and Urban Planning, 65(1), 41-52. https://doi.org/10.1016/S0169-2046(02)00236-0 
Bonaiuto, M., Fornara, F., \& Bonnes, M. (2006). Perceived residential environmental quality in middle- and low-extension Italian cities. European Review of Applied Psychology, 56(11), 23-34. https://doi.org/10.1016/j.erap.2005.02.011

Boomsma, A., \& Hoogland, J. J. (2001). The robustness of LISREL modeling revisited. In R. Cudeck, S. du Toit, \& D. Sörbom (Eds.), Structural equation models: present and future. A festschrift in honor of Karl Jöreskog (pp. 139-168). Scientific Software International.

Chang, S. S. (2001). Research method. Tsanghai Publishers.

Cheah, J. H., Ng, S. I., Lee, C., \& Teoh, K. G. C. (2014). Assessing technical and functional features of office buildings and their effects on satisfaction and loyalty. International Journal of Economics and Management, 8(S), 137-176.

Cheah, J. H., Ng, S. I., Ting, H., Memon, M. A., \& Loo, S. C. S. (2019). Customer orientation and office space performance: assessing the moderating effect of building grade using PLS-MGA. International Journal of Strategic Property Management, 23(2), 117-129. https://doi.org/10.3846/ijspm.2019.7437

Cheah, J. H., Ting, H., Thaichon, P., Fam, K. S., \& Bazylewich, M. (2020). Consumer attitude and intention toward ridesharing. Journal of Strategic Marketing, 1-22.

https://doi.org/10.1080/0965254X.2020.1733050

Chen, K. Y., \& Wang, C. H. (2011). Advanced statistical analysis using SPSS and AMOS. Wu-Nan Books.

Chen, S. M., \& Shiu, D. W. (2016). The effects of the customer relationship management on tenant satisfaction and loyalty an example from Tainan City. Journal of Architecture and Planning, 17(1), 7-8.

Chen, S. Y. (2003). Structural equation modeling: theory, techniques, and application of LISREL. Yeh Yeh Book Gallery.

Chen, Y. J. (2012). The relationships between residential satisfaction and the intention to move for the community residents [Master's thesis]. Kun Shan University Graduate Institute of Real Estate Development and Management.

Chiu, H. J. (2009). Quantitative research and statistical analysis (3rd ed.). Wu-Nan Books.

Chung, Y. Y., \& Su, W. K. (2014). The relationship between authentic leadership and quality of care-the mediating effect of nurse's psychological contract. Journal of Health and Care Science, 2(2), 71-84.

Cialdini, R. B., \& Goldstein, N. J. (2004). Social influence: compliance and conformity. Annual Review of Psychology, 55, 591621. https://doi.org/10.1146/annurev.psych.55.090902.142015

Directorate General of Budget, Accounting and Statistics Census GIS Platform. (2018). House ownership of ordinary households. https://census.dgbas.gov.tw/CensusGIS_ Tile/?ClassIndex $=1$

Dogge, P., \& Smeets, J. (2004). In search of customer loyalty. A research into the relationship between tenants' satisfaction and commitment. Journal of Applied Psychology, 6(3-4), $111-120$

Falco, J. (2017, October 27). Kingsley: renter satisfaction holds steady, renewal intent drops slightly. https://www.multifamilyexecutive.com/property-management/kingsley-renter-satisfaction-holds-steady-renewal-intent-drops-slightly_o

Fazio, R. H., \& Zanna, M. P. (1978). Attitudinal qualities relating to the strength of the attitude-behavior relationship. Journal of Social Experimental Psychology, 14(4), 398-408. https://doi.org/10.1016/0022-1031(78)90035-5

Fazio, R. H., \& Zanna, M. P. (1981). Direct experience and attitude-behavior consistency. In L. Berkowitz (Ed.), Advances in experimental social psychology (pp. 161-202). Academic. https://doi.org/10.1016/S0065-2601(08)60372-X
Fishbein, M., \& Ajzen, I. (1975). Belief, attitude, intention and behavior: an introduction to theory and research. AddisonWesley.

Flint, D. J., Blocker, C. P., \& Boutin, P. J. (2011). Customer value anticipation, customer satisfaction and loyalty: an empirical examination. Industrial Marketing Management, 40(2), 219230. https://doi.org/10.1016/j.indmarman.2010.06.034

Fornell, C., \& Larcker, D. (1981). Evaluating structural equation models with unobservable variables and measurement error. Journal of Marketing Research, 18(1), 39-50. https://doi.org/10.1177/002224378101800104

Freybote, J., \& Gibler, K. M. (2011). Trust in corporate real estate management outsourcing relationships. Journal of Property Research, 28(4), 341-360.

https://doi.org/10.1080/09599916.2011.592207

Fuentes-Blasco, M., Moliner-Velázquez, B., \& Gil-Saura, I. (2014). Effect of customer heterogeneity on the relationship satisfaction-loyalty. Revista Española de Investigación en Marketing ESIC, 18(2), 78-92. https://doi.org/10.1016/j.reimke.2014.06.002

Gasiorowska, A. (2014). The relationship between objective and subjective wealth is moderated by financial control and mediated by money anxiety. Journal of Economic Psychology, 43, 64-74. https://doi.org/10.1016/j.joep.2014.04.007

Gibler, K. M., Tyvimaa, T., \& Kananen, J. (2014). The relationship between the determinants of rental housing satisfaction and considering moving in Finland. Property Management, 32(2), 104-124. https://doi.org/10.1108/PM-02-2013-0009

Gounaris, S., Dimitriadis, S., \& Stathakopoulos, V. (2010). An examination of the effects of service quality and satisfaction on customers' behavioral intentions in e-shopping. Journal of Services Marketing, 24(2), 142-156.

https://doi.org/10.1108/08876041011031118

Hair, J. F., Black, W. C., Babin, B. J., Anderson, R. E., \& Tatham, R. L. (2006). Multivariate data analysis (6th ed.). Pearson University Press.

Hair, J., Anderson, R. E., Tatham, R. L., \& Black, W. C. (1998). Multivariate data analysis (7th ed.). A Global Perspective.

Henseler, J., Ringle, C. M., \& Sarstedt, M. (2015). A new criterion for assessing discriminant validity in variance-based structural equation modeling. Journal of the Academy of Marketing Science, 43(1), 115-135.

https://doi.org/10.1007/s11747-014-0403-8

Hong, X. M., \& Chang, C. O. (1993). A study of housing management and maintenance influence on housing quality. City and Planning, 20(2), 1-22.

Hui, E. C. M., Wong, F. K. W., Chung, K. W., \& Lau, K. Y. (2014). Housing affordability, preferences and expectations of elderly with government intervention. Habitat International, 43, 11-21. https://doi.org/10.1016/j.habitatint.2014.01.010

Hung, T.-Y., \& Chang, C.-O. (2002). An analysis of the management and maintenance modes of condominium in Taipei. City and Planning, 29(3), 421-444.

Hwang, Y. (2008). The impact of uncertainty avoidance, social norms and innovativeness on trust and ease of use in electronic customer relationship management. Electron Markets, 19(2), 89-98. https://doi.org/10.1007/s12525-009-0007-1

Kang, G. D. (2006). The hierarchical structure of service quality: integration of technical and functional quality. Managing Service Quality, 16(1), 37-50. https://doi.org/10.1108/09604520610639955

Kang, G., \& James, J. (2004). Service quality dimensions: an examination of Gronroos's service quality model. Managing Service Quality, 14(4), 277-295.

https://doi.org/10.1108/09604520410546806 
Kennedy, J. M., \& Schneider, U. (2000). Measuring customer satisfaction: why, what and how? Total Quality Management, 11(7), 883-896. https://doi.org/10.1080/09544120050135434

Kim, S., Lee, J., \& Yoon, D. (2015). Norms in social media: the application of theory of reasoned action and personal norms in predicting interactions with Facebook page like ads. Communication Research Reports, 32(4), 322-331. https://doi.org/10.1080/08824096.2015.1089851

Kirkpatrick, S., \& Tarasuk, V. (2011). Housing circumstances are associated with household food access among low-income urban families. Journal of Urban Health: Bulletin of the New York Academy of Medicine, 88(2), 284-296. https://doi.org/10.1007/s11524-010-9535-4

Kline, P. (1998). The new psychometrics: science, psychology and measurement. Routledge.

Kusbit, C., \& Sutton, J. (1991). Tenant retention: making it hard to leave. Journal of Property Management, 56(1), 18-20.

Lee, C. C. (2012). Brand loyalty to housing brokerage firms-from buyers' viewpoint. Management Review, 31(3), 73-100.

Lemke, F., Clark, M., \& Wilson, H. (2011). Customer experience quality: an exploration in business and consumer contexts using repertory grid technique. Journal of the Academy of Marketing Science, 39(6), 846-869.

https://doi.org/10.1007/s11747-010-0219-0

Lercher, P. (2003). Which health outcomes should be measured in health related environmental quality studies. Landscape and Urban Planning, 65(1), 63-72. https://doi.org/10.1016/S0169-2046(02)00238-4

Lin, S.-L., Chueh, J.-H., \& Cheng, Y.-C. (2016). The effect of brand attitude on brand loyalty and price premium: the mediating role of emotional brand attachment Taiwan. Journal of International Business Studies, 10(2), 123-140.

Liu, T. C., \& Wu, L. W. (2007). Customer retention and crossbuying in banking industry: an integration of service attributes, satisfaction and trust. Journal of Financial Services Marketing, 12(2), 132-145. https://doi.org/10.1057/palgrave.fsm.4760067

Malik, S. U. (2012). Customer satisfaction, perceived service quality. International Journal of Marketing Studies, 4(1), 6876. https://doi.org/10.5539/ijms.v4n1p68

McDougall, G. H. G., \& Levesque, T. (2000). Customer satisfaction with services: putting perceived value into the equation. Journal of Service Marketing, 14(5), 392-410. https://doi.org/10.1108/08876040010340937

Muhlebach, R. F. (1998). Tenant surveys benchmark success for management firms. National Real Estate Investor, 40(2), 159-160.

Myeda, N. E., Kamaruzzaman, S. N., \& Pitt, M. (2011). Measuring the performance of office buildings maintenance management in Malaysia. Journal of Facilities Management, 9(3), 181-199. https://doi.org/10.1108/14725961111148090

Nath, R., Tomov, S., \& Dongarra, J. (2010). Accelerating GPU kernels for dense linear algebra. In International Conference on High Performance Computing for Computational Science (pp. 83-92). Springer.

https://doi.org/10.1007/978-3-642-19328-6_10

Naudé, P., \& Buttle, F. (2000). Assessing relationship quality. Industrial Marketing Management, 29(4), 351-361. https://doi.org/10.1016/S0019-8501(00)00112-7

Oliver, R. L. (1997). Satisfaction: a behavioral perspective on the consumer. McGrew-Hill.

Onibokun, A. G. (1974). Evaluating consumers satisfaction with housing: an application of a system approach. Journal of the American Institute of Planners, 40(3), 189-200.

https://doi.org/10.1080/01944367408977468
Palm, P. (2016). Measuring customer satisfaction: a study of the Swedish real estate industry. Property Management, 34(4), 316-331. https://doi.org/10.1108/PM-08-2015-0041

Parasuraman, A. (1997). Reflections on gaining competitive advantage through customer value. Journal of the Academy of Marketing Science, 25(2), 154-161. https://doi.org/10.1007/BF02894351

Parasuraman, A., \& Grewal, D. (2000). The impact of technology on the quality-value-loyalty chain: a research agenda. Academy of Marketing Science Journal, 28(1), 168-174. https://doi.org/10.1177/0092070300281015

Peng, T. K., Kao, Y. T., \& Lin, C. C. (2006). Common method variance in management research: its nature, effects, detection, and remedies. Journal of Management, 23(1), 77-98.

Petty, R. E., \& Wegener, D. T. (1999). The elaboration likelihood model: current status and controversies. In S. Chaiken, \& Y. Trope (Eds.), Dual-process theories in social psychology (pp. 37-72). The Guilford Press.

Podsakoff, P. M., \& Organ, D. W. (1986). Self-reports in organizational research: problems and prospects. Journal of Management, 12(4), 531-544.

https://doi.org/10.1177/014920638601200408

Poll, H. F. P. M. V. (1997). The perceived quality of the urban residential environment: a multi-attribute evaluation [Ph.D. dissertation]. University of Groningen.

Rasila, H. (2009). Customer relationship quality in landlord-tenant relationship. Property Management, 28(2), 80-92. https://doi.org/10.1108/02637471011037107

Reinartz, W. J., Haenlein, M., \& Henseler, J. (2009). An empirical comparison of the efficacy of covariance-based and variancebased SEM. International Journal of Research in Marketing, 26(4), 332-344. https://doi.org/10.1016/j.ijresmar.2009.08.001

Robbins, S. P. (1994). Organizational behavior. Prentice-Hall.

Roos, D., \& Hahn, R. (2017). Does shared consumption affect consumers' values, attitudes, and norms? A panel study. Journal of Business Research, 77, 113-123.

https://doi.org/10.1016/j.jbusres.2017.04.011

Sanderson, D. C. (2019). Winning tenant's loyalty in the private rented sector. Property Management, 37(3), 390-417. https://doi.org/10.1108/PM-08-2018-0050

Sarstedt, M., Hair, J. F., Ringle, C. M., Thiele, K. O., \& Gudergan, S. P. (2016). Estimation issues with PLS and CBSEM: where the bias lies! Journal of Business Research, 69(10), 3998-4010. https://doi.org/10.1016/j.jbusres.2016.06.007

Satsangi, M., \& Kearns, A. (1992). The use and interpretation of tenant satisfaction surveys in British social housing. Environment and Planning C: Government and Policy, 10(3), 317-331. https://doi.org/10.1068/c100317

Seetharaman, A., Saravanan, A. S., Patwa, N., \& Bey, J. M. (2017). The impact of property management services on tenants' satisfaction with industrial buildings. The Journal of Asian Finance, Economics and Business, 4(3), 57-73. https://doi.org/10.13106/jafeb.2017.vol4.no3.57

Smith, J. R., Hogg, M. A., Martin, R., \& Terry, D. J. (2007). Uncertainty and the influence of group norms in the attitudebehaviour relationship. British Journal of Social Psychology, 46(4), 769-792. https://doi.org/10.1348/014466606X164439

Smith, R. E., \& Swinyard, W. R. (1983). Attitude behavior consistency: the impact of product trial versus advertising. Journal of Marketing Research, 20(3), 257-267. https://doi.org/10.1177/002224378302000304

Smith, R. E., \& Swinyard, W. R. (1988). Cognitive response to advertising and trial: belief strength, belief confidence and product curiosity. Journal of Advertising, 17(3), 3-14. https://doi.org/10.1080/00913367.1988.10673118 
Taylor, S., \& Todd, P. (1995a). Decomposition and crossover effects in the theory of planned behavior: a study of consumer adoption intentions. International Journal of Research in Marketing, 12(2), 137-155. https://doi.org/10.1016/0167-8116(94)00019-K

Taylor, S., \& Todd, P. (1995b). Assessing IT usage: the role of prior experience. MIS Quarterly, 19(4), 561-570. https://doi.org/10.2307/249633

Taylor, S., \& Todd, P. (1995c). Understanding information technology usage: a test of competing models. Information Systems Research, 6(2), 144-176. https://doi.org/10.1287/isre.6.2.144

Tikkanen, H., \& Alajoutsijarvi, K. (2002). Customer satisfaction in industrial markets: opening up the concept. Journal of Business and Industrial Marketing, 17(1), 25-42. https://doi.org/10.1108/08858620210415181

Tsang, M. K. (2009). Investigating the tenant satisfaction: retention link of office buildings in Hong Kong [HKU the- ses online (HKUTO)]. https://www.sapnaonline.com/ books/investigating-tenant-satisfaction-retention-link-meiki-1360964746-9781360964744

Turel, O., \& Serenko, A. (2006). Satisfaction with mobile services in Canada: an empirical investigation. Telecommunications Policy, 30(5-6), 314-331.

https://doi.org/10.1016/j.telpol.2005.10.003

Zheng, S., Cheng, Y., \& Ju, Y. (2019). Understanding the intention and behavior of renting houses among the young generation: evidence from Jinan, China. Sustainability, 11(6), 1507. https://doi.org/10.3390/su11061507

Zins, A. H. (2001). Relative attitudes and commitment in customer loyalty models: some experiences in the commercial airline industry. International Journal of Service Industry Management, 12(3), 269-294.

https://doi.org/10.1108/EUM0000000005521

\section{Appendix}

Table A1. Correlation coefficient of measurement variable

\begin{tabular}{|c|c|c|c|c|c|c|c|c|c|c|c|c|c|c|c|c|c|c|c|}
\hline & 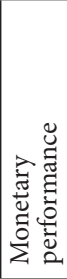 & 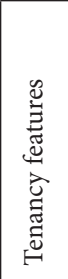 & 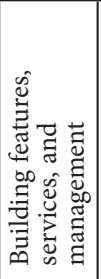 & 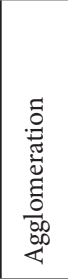 & 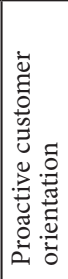 & 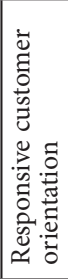 & 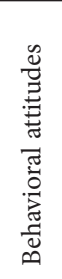 & 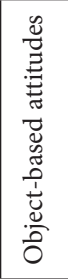 & 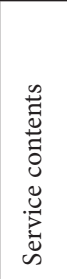 & 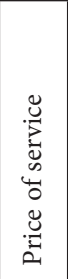 & 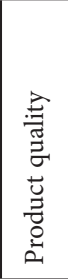 & 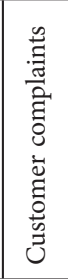 & 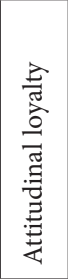 & 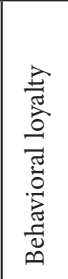 & 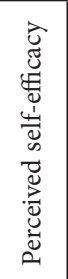 & 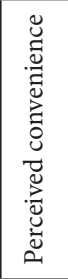 & 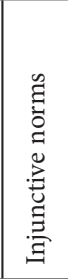 & 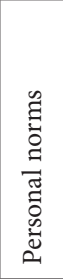 & 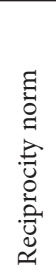 \\
\hline Monetary performance & 1.00 & & & & & & & & & & & & & & & & & & \\
\hline Tenancy features & 0.22 & 1.00 & & & & & & & & & & & & & & & & & \\
\hline $\begin{array}{l}\text { Building features, services, } \\
\text { and management }\end{array}$ & 0.23 & 0.44 & 1.00 & & & & & & & & & & & & & & & & \\
\hline Agglomeration & 0.14 & 0.34 & 0.42 & 1.00 & & & & & & & & & & & & & & & \\
\hline $\begin{array}{l}\text { Proactive customer } \\
\text { orientation }\end{array}$ & 0.09 & 0.47 & 0.29 & 0.32 & 1.00 & & & & & & & & & & & & & & \\
\hline $\begin{array}{l}\text { Responsive customer } \\
\text { orientation }\end{array}$ & 0.10 & 0.47 & 0.30 & 0.28 & 0.85 & 1.00 & & & & & & & & & & & & & \\
\hline Behavioral attitudes & 0.17 & 0.51 & 0.28 & 0.35 & 0.64 & 0.61 & 1.00 & & & & & & & & & & & & \\
\hline Object-based attitudes & 0.15 & 0.47 & 0.25 & 0.33 & 0.62 & 0.57 & 0.88 & 1.00 & & & & & & & & & & & \\
\hline Service contents & 0.18 & 0.51 & 0.36 & 0.28 & 0.74 & 0.71 & 0.60 & 0.53 & 1.00 & & & & & & & & & & \\
\hline Price of service & 0.31 & 0.33 & 0.36 & 0.27 & 0.41 & 0.36 & 0.39 & 0.32 & 0.56 & 1.00 & & & & & & & & & \\
\hline Product quality & 0.14 & 0.48 & 0.34 & 0.29 & 0.60 & 0.54 & 0.56 & 0.48 & 0.68 & 0.56 & 1.00 & & & & & & & & \\
\hline Customer complaints & 0.18 & 0.53 & 0.36 & 0.24 & 0.76 & 0.68 & 0.61 & 0.54 & 0.39 & 0.55 & 0.75 & 1.00 & & & & & & & \\
\hline Attitudinal loyalty & 0.30 & 0.49 & 0.36 & 0.20 & 0.55 & 0.53 & 0.52 & 0.49 & 0.58 & 0.50 & 0.55 & 0.57 & 1.00 & & & & & & \\
\hline Behavioral loyalty & 0.23 & 0.45 & 0.35 & 0.24 & 0.52 & 0.51 & 0.49 & 0.46 & 0.55 & 0.50 & 0.54 & 0.54 & 0.83 & 1.00 & & & & & \\
\hline Perceived self-efficacy & 0.22 & 0.47 & 0.42 & 0.31 & 0.39 & 0.41 & 0.50 & 0.44 & 0.49 & 0.37 & 0.46 & 0.52 & 0.43 & 0.46 & 1.00 & & & & \\
\hline Perceived convenience & 0.17 & 0.39 & 0.24 & 0.19 & 0.38 & 0.40 & 0.40 & 0.39 & 0.42 & 0.26 & 0.37 & 0.44 & 0.40 & 0.34 & 0.59 & 1.00 & & & \\
\hline Injunctive norms & 0.17 & 0.27 & 0.30 & 0.29 & 0.28 & 0.25 & 0.24 & 0.27 & 0.17 & 0.21 & 0.18 & 0.21 & 0.25 & 0.27 & 0.24 & 0.17 & 1.00 & & \\
\hline Personal norms & 0.18 & 0.24 & 0.10 & 0.18 & 0.24 & 0.19 & 0.28 & 0.29 & 0.20 & 0.16 & 0.19 & 0.17 & 0.25 & 0.27 & 0.14 & 0.19 & 0.19 & 1.00 & \\
\hline Reciprocity norm & 0.27 & 0.45 & 0.34 & 0.18 & 0.44 & 0.51 & 0.39 & 0.35 & 0.54 & 0.49 & 0.48 & 0.57 & 0.58 & 0.51 & 0.34 & 0.33 & 0.19 & 0.19 & 1.00 \\
\hline
\end{tabular}

